\title{
Reproductive dominance among honeybee workers in experimental groups of Apis mellifera capensis ${ }^{1}$
}

\author{
Ute E. SIMONa ${ }^{a}$, Robin F.A. MORITZ ${ }^{a}, b *$, Robin M. CREWE ${ }^{b}$ \\ ${ }^{a}$ Martin-Luther, Universität Halle, Wittenberg, Institut für Zoologie, Hoher Weg 4, 06099 Halle, Germany \\ ${ }^{b}$ University of Pretoria, Department of Zoology and Entomology, 0002 Pretoria, South Africa
}

Receveid 20 July 2004 - revised 10 December 2004 - accepted 16 December 2004

Published online 7 July 2005

\begin{abstract}
The fitness benefits of becoming a laying worker in a queenless social insect colony are high. Theoretical models predict that these benefits will lead to conflict among workers of different subfamilies in orphaned polyandrous or polygynous colonies of social insects. We studied the nature of this conflict among Apis mellifera capensis workers that were placed in small experimental groups without a queen. Characters directly related to reproductive dominance such as the queen substance (9-ODA) content of the mandibular glands, the activation of ovaries, and the production of eggs were recorded. Worker laid eggs were genotyped to measure the reproductive success of individual workers. There was a significant correlation between the amount of 9-ODA produced and ovary activation. Workers with fully developed ovaries (visible ova) who had laid eggs produced significantly more 9-ODA than similar workers with developed ovaries that had not laid eggs.
\end{abstract}

Apis mellifera capensis / worker reproduction / 9-ODA / individual fitness / DNA fingerprinting

\section{INTRODUCTION}

Division of labor is one of the primary characteristics of a honeybee colony. The most striking example of this is the division of reproductive labor, where a specific queen caste can be distinguished from the worker caste in the female sex. Usually the queen is the only reproductively dominant female in the honeybee colony, and worker reproduction is suppressed through a suite of semiochemicals released by the queen and the brood she produces (VerheijenVoogd, 1959; Velthuis, 1970; Hoover et al., 2003). Worker reproduction is exceedingly rare as long as the queen is present, only $1 \%$ of the workers have sufficiently developed ovaries to lay eggs (Visscher, 1996). Moreover worker laid eggs rarely survive, because they have a reduced viability (Pirk et al., 2004) and may be removed by workers (Ratnieks and Visscher, 1989). Reproductively dominant worker bees have been called pseudoqueens (Sakagami, 1958; Velthuis et al., 1990). Generally, however, only a very small percentage of honeybee workers develops into pseudoqueens, and the majority of the workers remains sterile (Page and Robinson, 1994; Moritz et al., 1996; Neumann and Moritz, 2002; Martin et al., 2004). Laying workers of the Cape Honeybee (Apis mellifera capensis Escholtz) have a particularly strong potential to become reproductively dominant in both queenright and queenless colonies (Hepburn and Radloff, 1998). Moreover, the eggs they lay are less frequently removed from cells (Moritz et al., 1999; Martin et al., 2002). The fitness gain of laying A. m. capensis workers seems to be particularly strong, because they can parthenogenetically

\footnotetext{
* Corresponding author: r.moritz@ zoologie.uni-halle.de
}

${ }^{1}$ Manuscript editor: Stefan Fuchs 
produce female offspring (thelytoky), which can develop into both workers and queens (Greeff, 1996; Moritz et al., 1996). Genetic studies have shown that the offspring of a laying worker are an identical clone with no (Moritz and Haberl, 1994) or very little recombination (Baudry et al., 2004). Since the latency period between queen loss and the onset of worker oviposition is only seven days (Ruttner and Hesse, 1981), strong competition among a group of laying workers has been observed within the first week after queen loss. This competition, which is partly governed by pheromonal competition (Moritz et al., 2000, 2003), results in strong intracolonial selection with only very few subfamilies producing pseudoqueens and offspring. Laying A. m. capensis workers produce a queen-like pheromone signal in the fatty acid secretion of the mandibular glands, typically with a high queen substance (9-ODA, (E)9-keto-2-decenoic acid) content (Crewe and Velthuis, 1980; Hemmling et al., 1979). Although 9-ODA is only one component of the queen mandibular gland complex (Slessor et al., 1988), it is a precise indicator of queenlike mandibular gland secretions (Crewe and Velthuis, 1980) and important for establishing dominance hierarchies among workers (Moritz and Hillesheim, 1985; Moritz et al., 2000). Dominant A. m. capensis workers produce 9-ODA (Hemmling et al., 1979; Crewe and Velthuis, 1980; Velthuis et al., 1990) and suppress ovary development in non reproductive "subordinate" workers (Hillesheim et al., 1989). Plettner et al. (1993) found no clear relationship between the pheromone secretions of workers and the ovarian development (although their data actually show suppressive effects of 9-ODA). One possible reason why they failed to find strong effects, may be that they tested worker bees from subspecies other than A. m. capensis, which express less pronounced dominance hierarchies. In order to test for the potential interaction between ovary development and pheromone production we take advantage of the extreme reproductive potential of $A$. m. capensis laying workers in this study. We use genetic markers to discriminate between those workers that have fully developed ovaries but lay no eggs or eggs removed by workers after oviposition and those that do produce viable eggs. We also use controlled experimental conditions to reduce environmental variance of hive conditions, to more clearly reveal the mechanisms establishing dominance hierarchies among laying worker honeybees.

\section{METHODS}

\subsection{Test animals}

A. m. capensis workers were taken from the brood combs of a brood- and queenright colony. Only one colony was used in this experiment since we were interested in intracolonial competition amongst the laying workers for the opportunity to be reproductively successful. These are usually young workers and not old foragers, which reside on the peripheral honey combs (Moritz and Southwick, 1992). A group of workers $(n=150)$ were immediately stored in ethanol, to serve as a control group to determine the subfamily frequency in the original colony. A further 100 workers were placed in each of 11 small containers $(10 \times 15 \times 5 \mathrm{~cm})$, that were equipped with an empty piece of comb $(4 \times 11 \mathrm{~cm})$. The bees were supplied with pollen and honey ad libitum and kept in an incubator $\left(34^{\circ} \mathrm{C}\right.$, rel. humidity $\left.65 \%\right)$. After 10 days all surviving workers were collected and decapitated. The head was placed in a vial containing $500 \mu \mathrm{L}$ dichloromethane as a solvent, the routine procedure to extract the fatty acids from the mandibular gland (Crewe and Velthuis, 1980). The rest of the body was stored in an Eppendorf tube with absolute ethanol for DNA analysis. The combs containing the eggs were stored in a freezer at $-80^{\circ} \mathrm{C}$ also for later DNA analyses.

\subsection{Gas chromatography}

The heads were removed from the solvent, which was evaporated just to dryness with a stream of $\mathrm{N}_{2}$. The residue was then redissolved in $20 \mu \mathrm{L}$ internal standard $( \pm 1 \mathrm{mg}$ octanoic acid and tetradecane in $1 \mathrm{~mL}$ dichloromethane) and $20 \mu \mathrm{L}$ (bis-trimethylsilyltrifluoroacet-amid BSTFA). $1 \mu \mathrm{L}$ of this solution was injected into a gas chromatograph (Hewlett Packard 5890) fitted with a split-splitless inlet and a $25 \mathrm{~m} \times 0.32 \mathrm{~mm}$ methyl silicone coated fused silica capillary column. The split-splitless injection technique was used with heptane as the solvent plug. The carrier gas was hydrogen with a flow rate of $1 \mathrm{~mL} /$ $\mathrm{min}$, and the oven temperature was as follows; $60^{\circ} \mathrm{C}$ for $1 \mathrm{~min}$, then heated at $50^{\circ} \mathrm{C} / \mathrm{min}$ to $110^{\circ} \mathrm{C}$, then $3{ }^{\circ} \mathrm{C} / \mathrm{min}$ from $110^{\circ} \mathrm{C}$ to $220^{\circ} \mathrm{C}$ and held at $220^{\circ} \mathrm{C}$ for $10 \mathrm{~min}$. Chromatograms were recorded and peak areas quantified using HP ChemStation software. Peaks were identified by their retention times relative to tetradecane. The amount of 9-ODA (Gehrke and Leimer, 1971) of 9-ODA in each of the samples was measured relative to tetradecane as the internal standard. 


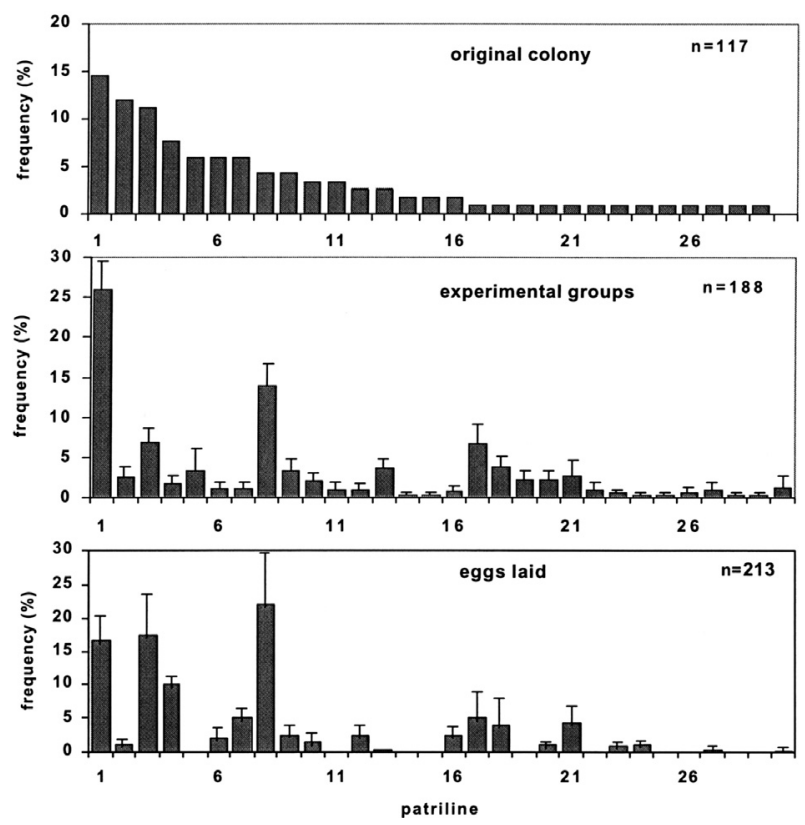

Figure 1. Frequency (\%) of subfamilies found in the original colony (top) in the experimental groups (center) and in the eggs produced by laying workers (bottom).

\subsection{Genotyping of adult workers and eggs}

The Chelex method (Walsh et al., 1991) was used for DNA extraction of adult worker flight muscle (control and experimental groups). The eggs were removed from the cells with a fine brush and transferred directly into $50 \mu \mathrm{L}$ of Chelex (5\%). The sample was heated for $10 \mathrm{~min}$ at $95^{\circ} \mathrm{C}$, vortexed for 5$10 \mathrm{~s}$ and centrifuged for $3 \mathrm{~min}$ at $13000 \mathrm{~g}$. One $\mu \mathrm{L}$ was taken from the top of the solution to be used in the polymerase chain reaction (PCR).

Paternity was determined with five polymorphic microsatellite loci (B124, A7, A76, A107, A113; Estoup et al., 1994, 1995) on an automated capillary DNA sequencer (ABI 310). The polymerase chain reactions (PCRs) were conducted as multiple reactions with either triplets or pairs of loci with the POP4 polymer and a $47 \mathrm{~cm}$ capillary $(\phi 50 \mu \mathrm{m})$ for fragment analyses, $5 \mathrm{~s}$ injection and a total running time of $21 \mathrm{~min}$. The genotype of the father siring a subfamily was inferred by comparing the queen's genotype with that of the worker offspring. Worker alleles that were not present in the queen were interpreted as paternal alleles. If both alleles of a worker at a given locus were identical to those of the mother both were considered to be potentially of male origin with a 50\% chance. Since the offspring of the laying workers are clonal, they have the same genotype as their mother laying worker.

\subsection{Ovary dissection}

The ovaries of the genetically characterized bees were dissected under a dissecting microscope and scored in four different categories. $0=$ completely undeveloped (thread like with no contents); $1=$ small ovaries but with slightly visible contents; $2=$ large ovaries but no visible ova; 3 = as 2 but with visibly separate ova.

\section{RESULTS}

\subsection{Genoptyping}

In total 188 workers and 231 eggs out of 11 experimental groups and 117 workers of the control sample were genotyped. The colony was composed of 30 subfamilies. The distribution of the workers and the eggs for each patriline is presented in Figure 1. Only one patriline (\#30) was lacking in the sample (117 workers) taken from the colony. Given that we sampled every patriline more than once (total sample = 295 workers), we feel confident that we obtained all the patrilines present in the colony.

The frequency of the patrilines of the randomly sampled workers from the colony (Fig. 1) was compared with the frequency of workers 


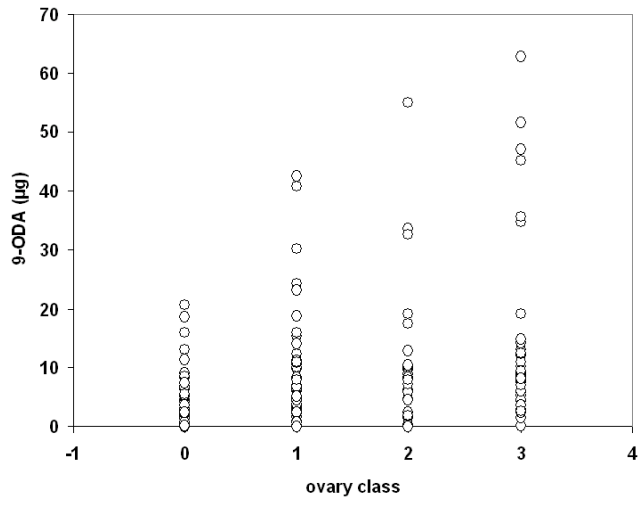

Figure 2. Scatter plot of the correlation $(\mathrm{r}=0.293$, $\mathrm{N}=149, P<0.01)$ between the ovary status $(0-3)$ of the workers and the amount of the queen pheromone (9-ODA) they produced.

that survived in the experimental groups. The distribution of the frequency differed significantly $\left(\chi^{2}=117.95, \mathrm{df}=29, P<0.01\right)$. Some subfamilies were more frequent (e.g. \#1, \#8, \#17) whereas others showed greatly reduced frequencies (\#2, \#4, \#7)

The genotypic data of the worker laid eggs revealed that only workers from 18 of the 30 subfamilies in the experimental groups were reproductively active (Fig. 1c). Three patrilines $(\# 1, \# 3$,\#8) proved to be particularly successful and produced more than half of the eggs. Subfamilies have a common dam but different drone sires. Since we could identify the reproduction of individual workers, it was possible to dissect the total variance into within subfamily variance (among workers of the same patriline, mean square $=0.039, \mathrm{df}=26)$ and between subfamily variance (mean square $=$ $0.152, \mathrm{df}=16$ ) by an analysis of variance. This allowed the estimation of the genetic variance component for the number of surviving eggs laid via a maternal halfsib analysis and an intraclass correlation (Falconer, 1989). As a result $70.0 \%$ of the total variance were estimated to be due to genetic variance (heritability in the broader sense $h^{2}=0.7$ ).

\subsection{Relationship between the produc- tion of 9-ODA and the ovary status}

Spearman's rank correlation showed a significant positive correlation between the amount

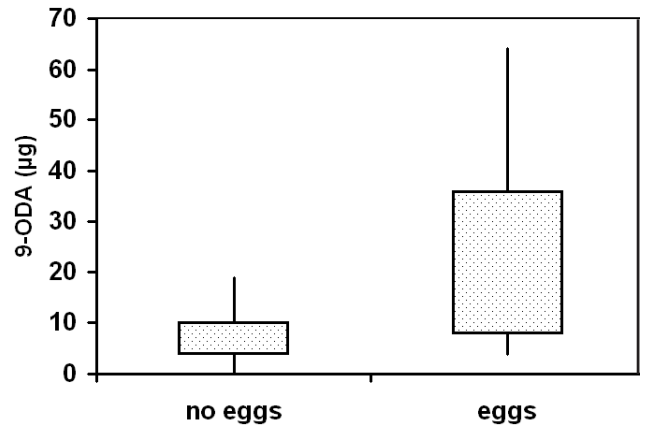

Figure 3. Box (25\%-75\% limits) and whisker (minmax) plot of the amount of worker produced 9-ODA. Left: workers that had fully developed ovaries but whose egg were not represented in the egg samples. Right: Workers that had equally developed ovaries but had eggs present in the egg samples.

of 9-ODA and the ovary status $(\mathrm{r}=0.293, \mathrm{~N}=$ $149, P<0.01$ ) (Fig. 2). However, there was considerable residual variance. Many workers had a low 9-ODA signal even in the highly developed ovary group. Moreover not all workers with developed ovaries were represented in the eggs sampled in the experimental groups. We therefore divided the group of bees with ovary status 3 (fully developed) into those which were (group 3A) and those which were not represented in the egg sample (group 3B). The amount of 9-ODA produced differed significantly between these two groups (MannWhitney U test, $P<0.05$ ) (Fig. 3) and workers whose eggs were present in combs of the experimental cages had a higher 9-ODA level, ranging up to $65 \mu \mathrm{g}$ per mandibular gland extract.

\section{DISCUSSION}

Our data show that not all A. m. capensis workers have the same potential to develop into laying workers and successfully produce offspring. This evidence supports previous reports of a high genetic variance for worker reproduction (Moritz and Hillesheim, 1985; Hillesheim, 1987; Hillesheim et al., 1989; Moritz et al., 1996) that has also been found in non-capensis honeybees (Page and Robinson, 1994; Martin et al., 2004). Intragroup selection among the various subfamilies changes the genotypic composition in queenless units relatively quickly 
(Neumann and Moritz, 2002). Our experimental conditions with queenless worker groups and no brood were designed to facilitate worker competition. Since laying workers of $A$. m. capensis produce substantial amounts of the queen pheromone (Wossler, 2002), and inhibit the development of other workers' ovaries (Hepburn et al., 1991; Neumann and Hepburn, 2002), it seems highly likely that pheromones are involved in the selection of reproductive workers (Moritz et al., 2003). The workers with the most developed ovaries had significantly more 9-ODA than those with less developed ovaries. The 9-ODA production of potential reproductives with ovary status 3 was significantly different between those workers which produced surviving eggs and those that had eggs in their ovaries but did not have eggs represented in the egg sample. Since we expect that workers with ovary status 3 should actually lay eggs, it seems most likely that these were removed from the cells by other workers. The reproductive individuals that laid surviving eggs, produced on average $18.1 \mu \mathrm{g}$ 9-ODA which is equivalent to the amount found in laying workers in natural colonies by Crewe and Velthuis (1980). This shows that our experimental conditions did not affect the development of a natural mandibular gland signal. Our data support Hepburn (1992), who reported that ovary development and becoming pheromonally queen-like co-vary. The level of 9-ODA production seems to be an important indicator of reproductive success.

Clearly, not all of the surviving workers developed into laying pseudoqueens. In fact the majority remained sterile. Workers from 3 out of the 30 subfamilies produced more than $50 \%$ of the offspring. Consequently worker reproduction has a high repeatability among subfamilies and the heritability estimate for this character was as high as $\mathrm{h}^{2}=0.70$. These results are in line with previous observations (Moritz and Hillesheim, 1985; Moritz et al., 1996) that showed a high genetic variance and strong intracolonial selection in dequeened experimental groups and colonies.

The intracolonial selection processes which are necessary to establish the pattern of worker reproduction in colonies of the Cape honeybee make it very clear that even in highly evolved social species such as honey bees, individual selection continues to play a role in shaping colonial phenotypes. This does not exclude selection that also operates at the colonial level (Korb and Heinze, 2004), but shows that we will fail to understand evolutionary processes in insect societies if we focus only on one level of selection, either individual or colony level selection.

\section{ACKNOWLEDGEMENTS}

This work was supported by the Deutsche Forschungsgemeinschaft (RFAM), the National Research Foundation (South Africa) (RMC) and the VW foundation (RFAM, RMC). We wish to thank Elsie van der Westhuisen for helping with the GC runs.

Résumé - Dominance de reproduction parmi les ouvrières d'abeilles (Apis mellifera capensis) en groupes expérimentaux. Les ouvrières pondeuses de l'Abeille domestique (Apis mellifera L.) peuvent se transformer en pseudo-reines (Sakagami, 1958; Velthuis et al., 1990), qui se caractérisent par des ovaires développés et un bouquet phéromonal des glandes mandibulaires semblable à celui des reines. Les pseudo-reines de l'Abeille du Cap (A. m. capensis) se caractérisent par une teneur en acide céto- 9 décène- 2 oïque (9ODA = substance royale) particulièrement élevée (Wossler, 2002). Pourtant seules quelques ouvrières se transforment en pseudo-reines et inhibent, par leur production de phéromone, le développement ovarien des autres ouvrières (Moritz et al., 2003).

Nous avons étudié le rapport entre la production de phéromone, le développement ovarien et les œufs survivants dans 11 groupes expérimentaux de 100 ouvrières chacun provenant d'une même colonie (A. m. capensis). Au bout de $10 \mathrm{j}$ les ouvrières et les œufs qu'elles ont pondus ont été récoltés. Nous avons mesuré par chromatographie en phase gazeuse la quantité d'acides gras présents dans la sécrétion des glandes mandibulaires de ces ouvrières et réparti en quatre classes le degré d'activation des ovaires, après dissection sous le microscope. L'analyse de l'ADN par les microsatellites (locus: B124, A7, A76, A107, A113; Estoup et al., 1994, 1995) a permis d'assigner les ouvrières et leurs œufs aux diverses sous-familles de la colonie. On a détecté au total 30 sous-familles ( $\mathrm{n}=295$ ouvrières, Fig. 1 ). Nous avons trouvé une corrélation significative entre le développement ovarien et la production de 9ODA (Fig. 2) et avons pu établir une variance génétique importante pour les caractères testés (Tab. I). Pourtant de nombreuses ouvrières, bien qu'ayant des ovaires développés, n'ont produit qu'une faible quantité de 9ODA. Nous avons donc comparé les quantités de 9ODA entre les ouvrières aux ovaires totalement développés qui donnaient des descendants et celles qui n'en donnaient pas. Les ouvrières qui avaient pondu des œufs se caractérisaient par une quantité de 9ODA significative plus forte (Fig. 3). 
Le 9ODA est donc un indicateur fiable pour la dominance de reproduction des ouvrières pondeuses. Nous avons pu montrer à nouveau que la variance génétique est un facteur important dans l'établissement de la hiérarchie de dominance chez les abeilles ; elle peut s'expliquer par un équilibre entre la sélection intracoloniale individuelle et la sélection au niveau de la colonie.

Apis mellifera capensis / ouvrière pondeuse / 9-ODA / fitness individuelle / empreinte génétique

Zusammenfassung - Reproduktive Dominanz bei Arbeiterinnen der Honigbiene in experimentellen Gruppen von Apis mellifera capensis. Legende Arbeiterinnen der Honigbiene (Apis mellifera) können sich zu Pseudoköniginnen entwickeln (Sakagami, 1958; Velthuis et al., 1990), die sich durch entwickelte Ovarien sowie ein königinnenähnliches Pheromonbouquet in den Mandibeldrüsen auszeichnen. Pseudoköniginnen der Kaphonigbiene (A. $m$. capensis) zeichnen sich durch einen besonders hohen Gehalt an (E)-9-Keto-2-decensäure (9ODA = Königinnensubstanz) aus (Wossler, 2002). Nur wenige Arbeiterinnen entwickeln sich jedoch zur Pseudokönigin (Moritz et al., 2003), die durch ihre Pheromonproduktion andere Arbeiterinnen in ihrer Ovaraktivierung unterdrücken.

In dieser Arbeit untersuchen wir den Zusammenhang zwischen Pheromonproduktion, Ovarentwicklung und tatsächlich überlebenden Eier in elf experimentellen Gruppen mit je 100 Arbeiterinnen aus einem Volk (A. m. capensis). Nach 10 Tagen wurden die Arbeiterinnen und die von ihnen gelegten Eier abgesammelt. Bei den Arbeiterinnen quantifizierten wir die Fettsäuren im Mandibeldrüsensekret gaschromatographisch, bestimmten mikroskopisch die Aktivierung der Ovarien in vier Klassen und ermittelten die Zugehörigkeit der Arbeiterinnen und die Eier zu den jeweiligen Unterfamilien im Bienenvolk mithilfe einer Mikrosatelliten-DNA-Analyse (Loci: B124, A7, A76, A107, A113; Estoup et al., 1994; Estoup 1995). Es wurden insgesamt 30 Subfamilien dedektiert ( $\mathrm{n}=295$ Arbeiterinnen, Abb. 1). Wir fanden eine signifikante Korrelation zwischen Ovarentwicklung und 9ODA-Produktion (Abb. 2) und konnten eine beachtliche genetische Varianz für die getesteten Merkmale feststellen (Tab. I). Dennoch gab es viele Arbeiterinnen, die trotz stark entwickelter Ovarien nur geringe 9ODA-Produktion zeigten. Wir verglichen daher die 9ODA Mengen zwischen Arbeiterinnen mit voll entwickelten Ovarien, die Nachkommen erzeugten und solchen die keine erzeugten. Arbeiterinnen, die Eier gelegt hatten, zeichneten sich durch eine signifikant höhere 9ODA Produktion aus (Abb. 3).

9ODA zeigt sich daher als zuverlässiger Indikator für reproduktive Dominanz legender Arbeiterinnen. Wir konnten erneut zeigen, dass genetische Varianz ein wichtiger Faktor bei der Etablierung von Dominanzhierarchien bei Honigbienen ist, die plausibel durch ein Gleichgewicht zwischen intrakolonialer individueller Selektion und Selektion auf der Kolonieebene erklärt werden kann.

Apis mellifera capensis / Arbeiterinnenreproduktion / 9-ODA / individuelle Fitness / DNA Fingerprinting

\section{REFERENCES}

Baudry E., Kryger P., Allsopp M., Koeniger N., Vautrin D., Mougel F., Cornuet J.M., Solignac M. (2004) Whole-genome scan in thelytokous-laying workers of the Cape Honeybee (Apis mellifera capensis): central fusion, reduced recombination rates and centromere mapping using half-tetrad analysis, Genetics 167, 243-252.

Crewe R.M., Velthuis H.H.W. (1980) False queens: a consequence of mandibular gland signals in worker honey bees, Naturwissenschaften 67, 467469.

Estoup A., Solignac M., Cornuet J.M. (1994) Precise assessment of the number of patrilines and of genetic relatedness in honeybee colonies, Proc. R. Soc. Lond. B 258, 1-7.

Estoup A., Garnery L., Solignac M., Cornuet J.M. (1995) Microsatellite variation in honey bee (Apis mellifera L.) populations: Hierarchical genetic structure and test of the infinite allele and stepwise mutation models, Genetics 140, 679-695.

Falconer D.S. (1989) Introduction to Quantitative Genetics, Longman, Harlow.

Gehrke C.W., Leimer K. (1971) Trimethylsilylation of amino acids derivatization and chromatography, $\mathrm{J}$. Chromatogr. 57, 219-238.

Greeff J.M. (1996) Effects of thelytokous worker reproduction on kin selection and conflict in the Cape honeybee, Apis mellifera capensis, Phil. Trans. R. Soc. Lond. B 351, 617-625.

Hemmling C., Koeniger N., Ruttner F. (1979) Quantitative Bestimmung der 9-Oxodecensäure im Lebenszyklus der Kapbiene (Apis mellifera capensis Escholtz), Apidologie 10, 227-240.

Hepburn H.R. (1992) Pheromonal and ovarial development covary in Cape worker honeybees, Apis mellifera capensis, Naturwissenschaften 79, 523524.

Hepburn H.R., Radloff S.E. (1998) Honeybees of Africa, Springer, Berlin Heidelberg New York.

Hepburn H.R., Magnuson P., Herbert L., Whiffler L.A. (1991) The development of laying workers in field colonies of the Cape honeybee, J. Apic. Res. 30, 13-16.

Hillesheim E. (1987) Does worker dominance reduce group fitness of honeybees (Apis mellifera capensis Escholtz)? in: Eder J., Rembold H. (Eds.), Chemistry and Biology of Social Insects, Peperny, Munich, pp. 360-361.

Hillesheim E., Koeniger N., Moritz R.F.A. (1989) Colony performance in honeybees (Apis mellifera capensis Esch.) depends on the proportion of subordinate and dominant workers, Behav. Ecol. Sociobiol. 24, 291-296. 
Hoover S.E. Keeling C.I., Winston M.L., Slessor K.N (2003) The effect of queen pheromones on worker honey bee ovary development, Naturwissenschaften 90, 477-480.

Korb J., Heinze J. (2004) Multilevel selection and social evolution in insect societies, Naturwissenschaften 91, 291-304.

Martin S., Beekman M., Wossler T.C., Ratnieks F.L.W. (2002) Parasitic Cape honeybee workers, Apis mellifera capensis, evade policing, Nature 415, 163-165.

Martin C.G., Oldroyd B.P., Beekman M. (2004) Differential reproductive success among subfamilies in queenless honeybee (Apis mellifera) colonies, Behav. Ecol. Sociobiol. 56, 42-49.

Moritz R.F.A., Haberl M. (1994) Lack of meiotic recombination in thelytokous parthenogenesis of laying workers of the Cape honeybee (Apis mellifera capensis), Heredity 73, 98-102.

Moritz R.F.A., Hillesheim E. (1985) Inheritance of dominance in honeybees (Apis mellifera capensis Esch.), Behav. Ecol. Sociobiol. 17, 87-89.

Moritz R.F.A., Southwick E.E. (1992) Bees as Superorganisms, Springer, Berlin Heidelberg New York.

Moritz R.F.A., Kryger P., Allsopp M.H. (1996) Competition for royalty in bees, Nature 384,31 .

Moritz R.F.A., Kryger P., Allsopp M. (1999) Lack of worker policing in the Cape Honeybee (Apis mellifera capensis), Behaviour 136, 1079-1092.

Moritz R.F.A., Lattorff H.M.G., Crewe R.M. (2003) Honeybee workers (Apis mellifera capensis) compete for producing queen-like pheromone signals, Proc. R. Soc. Lond. 271, S98-S100.

Moritz R.F.A., Simon U.E., Crewe R.M. (2000) Pheromonal contest between honeybee workers (Apis mellifera capensis), Naturwissenschaften 87, 395-397.

Neumann P., Hepburn H.R. (2002) Behavioural basis for social parasitism of Cape honeybees (Apis mellifera capensis), Apidologie 33, 165-192.

Neumann P., Moritz R.F.A. (2002) The Cape honeybee phenomenon: The sympatric evolution of a social parasite in real time? Behav. Ecol. Sociobiol. 52, 271-281.

Page R.E., Robinson G.E. (1994) Reproductive competition in queenless honeybee colonies (Apis mellifera L.), Behav. Ecol. Sociobiol. 35, 99-107.
Pirk C.W.W., Neumann P., Hepburn H.R., Moritz R.F.A., Tautz J. (2004) Egg viability and worker policing in honey bees, Proc. Natl. Acad. Sci. (USA) 101, 8649-8651.

Plettner E., Slessor K.N., Winston M.L., Robinson G.E., Page R.E. (1993) Mandibular gland components and ovarian development as measures of caste differentiation in the honey bee, J. Insect Physiol. 39, 235-240.

Ratnieks F.L.W., Visscher P.K. (1989) Worker policing in the honeybee, Nature 342, 796-797.

Ruttner F., Hesse B. (1981) Rassenspezifische Unterschiede in der Ovarienentwicklung und Eiablage von weisellosen Arbeiterinnen der Honigbiene Apis mellifera, Apidologie 12, 159-183.

Sakagami S.F. (1958) The false queen: fourth adjustive response in dequeened colonies, Behaviour 8, 280-296.

Slessor K.N., Kaminski L., King G.G.S., Borden J.H., Winston M.L. (1988) Semiochemical basis of the retinue response to queen honey bees, Nature 332, 354-356.

Velthuis H.H.W. (1970) Ovarian development in Apis mellifera worker bees, Entomol. Exp. Appl. 13, 377-394.

Velthuis H.H.W., Ruttner F., Crewe R.M. (1990) Differentiation in reproductive physiology and behaviour during the development of laying worker honey bees, in: Engels W. (Ed.), Social Insects, Springer, Berlin Heidelberg New York, pp. 231-243.

Verheijen-Voogd C. (1959) How worker bees perceive the presence of their queen, $\mathrm{Z}$. Vgl. Physiol. 41, 527-582.

Visscher P.K. (1996) Reproductive conflict in honey bees: a stalemate of worker egg laying and policing, Behav. Ecol. Sociobiol. 39, 237-244.

Walsh P.S., Metzger D.A., Higuchi R. (1991) Chelex ${ }^{\circledR}$ 100 as a medium for simple extraction of DNA for PCR-based typing from forensic material, BioTechniques 10, 506-513.

Wossler T.C. (2002) Pheromone mimicry by Apis mellifera capensis social parasites leads to reproductive anarchy in host Apis mellifera scutellata colonies, Apidologie 33, 139-163. 